Integrated Water Resources Management in the Mediterranean Region 

Redouane Choukr-Allah • Ragab Ragab

Rafael Rodriguez-Clemente

Editors

\section{Integrated Water \\ Resources Management \\ in the Mediterranean Region}

Dialogue Towards New Strategy

黑 Springer 


\author{
Editors \\ Redouane Choukr-Allah \\ Salinity and Plant Nutrition Laboratory \\ Institute of Agronomy \\ and Veterinary Hassan II \\ Agadir, Morocco \\ Rafael Rodriguez-Clemente \\ Institute of Environmental Assessment \\ and Water Studies (IDAEA-CSIC) \\ Barcelona, Spain
}

\author{
Ragab Ragab \\ Hydrological Processes Division \\ Centre for Ecology and Hydrology, CEH \\ Wallingford, Oxfordshire, UK
}

\author{
ISBN 978-94-007-4755-5 \\ ISBN 978-94-007-4756-2 (eBook) \\ DOI 10.1007/978-94-007-4756-2 \\ Springer Dordrecht Heidelberg New York London
}

\author{
Library of Congress Control Number: 2012948957
}

(C) Springer Science+Business Media Dordrecht 2012

This work is subject to copyright. All rights are reserved by the Publisher, whether the whole or part of the material is concerned, specifically the rights of translation, reprinting, reuse of illustrations, recitation, broadcasting, reproduction on microfilms or in any other physical way, and transmission or information storage and retrieval, electronic adaptation, computer software, or by similar or dissimilar methodology now known or hereafter developed. Exempted from this legal reservation are brief excerpts in connection with reviews or scholarly analysis or material supplied specifically for the purpose of being entered and executed on a computer system, for exclusive use by the purchaser of the work. Duplication of this publication or parts thereof is permitted only under the provisions of the Copyright Law of the Publisher's location, in its current version, and permission for use must always be obtained from Springer. Permissions for use may be obtained through RightsLink at the Copyright Clearance Center. Violations are liable to prosecution under the respective Copyright Law.

The use of general descriptive names, registered names, trademarks, service marks, etc. in this publication does not imply, even in the absence of a specific statement, that such names are exempt from the relevant protective laws and regulations and therefore free for general use.

While the advice and information in this book are believed to be true and accurate at the date of publication, neither the authors nor the editors nor the publisher can accept any legal responsibility for any errors or omissions that may be made. The publisher makes no warranty, express or implied, with respect to the material contained herein.

Printed on acid-free paper

Springer is part of Springer Science+Business Media (www.springer.com) 


\section{Foreword}

Most Mediterranean countries face challenges on two fronts, with regard to managing water resources in a sustainable manner and ensuring affordable and reliable water service delivery to farmers, households and industries. In general, water management in southern Mediterranean countries has suffered from poor accountability (both external to service users and internal within resource management and service delivery organizations). More and more investments are being required to remedy the deferred maintenance of already installed hydraulic infrastructures in the region.

As early as 2015, almost all southern Mediterranean countries will be below the level of severe water scarcity at less than $500 \mathrm{~m}^{3}$ per capita per year. Nine countries will be below $200 \mathrm{~m}^{3}$, six of which below $100 \mathrm{~m}^{3}$ and climate change will worsen the situation. Over $85 \%$ of fresh water is used for agriculture, with more than half wasted due to inefficient use practices. Efficiency levels of water for human use are also low, even in countries under chronic stress. Water availability is a prerequisite for the sustainable development of the Mediterranean region, which is characterized by water scarcity and extreme events of droughts and floods. Major current and future problems with fresh water resources in this region arise from the pressure to meet agricultural, human and industrial needs of a fast-growing economy that generates growing imbalances between water demand and supply. Management of limited water resources has taken many different forms and directions throughout the Mediterranean, but the continuous interaction between the peoples living on its shores has produced a common history and culture. In this context, there is an urgent need for action in order to integrate water management in national development plans, promote water considerations within cross-sectoral policies, and to introduce mainstream climate change adaptation into IWRM planning. This necessitates developing appropriate tools, improving the capacity building of water managers, raising public awareness and promoting water-sensitive environmental education, as well as setting up water partnerships at regional and national levels.

The objective of this book is to put together the knowledge developed on both sides of the Mediterranean about the issues related to Integrated Water Resources 
Management. This has been carried out by compiling several experiences produced in a number of reports, books, and conceptual frameworks describing the results of the internal and external debates organized within the Mediterranean region. The main aim of this book is to review the results of MELIA deliverables and the results of discussions that took place among a large spectrum of stakeholders and the recommendations to facilitate dialogues between Mediterranean countries on national IWRM planning, effective water governance, water and climate relationship, water demand management, water financing and the involvement of the private sector, as well as river basin management and transboundary water resources. We hope that the topics addressed by the different chapters will give additional value to our knowledge in this field and contribute to the improvement of the regional water planning and management under scarcity conditions in order to enhance sustainable development in the Mediterranean region.

The book is structured into four main parts, covering a wide range of topics related to Integrated Water Resources Management in the Mediterranean region.

The chapters of this book are organized so that they present observations and analyses of various aspects of IWRM through:

- First, and most significant, is to focus on the IWRM in the Mediterranean in the light of the European Water Framework Directive experience gained and the lessons learnt. It includes an assessment of water availability and water management and countries' strategies and adaptations to water scarcity conditions.

- Second, to discuss the impact of climate and land use changes on the Mediterranean region's water resources management, what strategy needs to be adopted to face these changes, and also what tools and guidelines are used to promote the sustainable water management, including the application of the integrated hydrological modelling system, IHMS and appropriate agricultural practices.

- Third, to tackle the manifold aspects of water quality deterioration in the Mediterranean through securing sufficient water knowledge and advancing monitoring and data collection efforts. The aim is to create a comprehensive regional and national assessment plan and to draw practical management solutions to face the emerging challenges and the existing key obstacles. In this part, we evaluate the potentials of wastewater reuse in the Mediterranean region, and the measures towards depollution of the Mediterranean Sea and the perspective of ecological sanitation scheme as a solution for rural areas.

- Fourth, to promote widely agreed solutions and promote the convergence of the water policies in the Euro-Mediterranean region on the basis of the Water Framework Directive recommendations. This part addresses water policies, governance and social issues in the Mediterranean countries and identifies risks, actions and opportunities for a water long-term strategy in the Mediterranean. We also share the common knowledge in relation to the water governance conceptual frameworks and analysis of gender roles in connection with water resources management and develop water security for food security nexus. 
We hope that the book will be of interest to a wide audience involved in water resources management, NGOs, operators, politicians, water authorities and researchers working in this field.

Finally, we would like to thank all the authors of this book for their time and effort in preparing this comprehensive compilation of research papers.

Redouane Choukr-Allah

Ragab Ragab

Rafael Rodriguez-Clemente 



\section{Preface}

The Mediterranean region is characterized by the limited and irregular availability of water resources, both in time (summer drought, interannual droughts) and in space (dry in the south). The region accounts for $10 \%$ of the world population with renewable water resources of less than $1,000 \mathrm{~m}^{3}$ water/inhabitant/year. The continuous growth in urbanization, tourism, irrigation and population increases tensions among sectors and causes conflicts in many countries and in regions where consumption has already reached or exceeded the amount of available water resources.

The Mediterranean countries are also the most vulnerable to global climate change. Studies have shown that the people of the Mediterranean can expect more forest fires and loss of agricultural land than any other region in the world. In the future, the region is expected to deal with more frequent and severe water shortages. Southern Mediterranean countries have a constant or shrinking water supply, but demand from competing users is rising steadily. Tourism rises steadily year after year, with the Mediterranean accounting for approximately one-third of all international tourism. Also increasing is the water demand to meet the steadily growing population requirement. The stable, ageing population in the northern Mediterranean is countered by a rapidly rising population in southern countries. But the biggest drain on resources is agriculture. Farming is the largest industry in terms of jobs in many Mediterranean countries. It is also one of the most water intensive human activities, with irrigation accounting for up to $60 \%$ of all water usage. Simply rising populations, the growing tourism trade and agriculture have led to a greater demand for water. Depending on where in the region, the Mediterranean contains arid or semi-arid areas, regularly having to deal with water scarcity and extreme events such as droughts and floods. This is a significant problem now, but when climate change is also factored in, water is expected to become a commodity which has the potential to become an acute problem for Mediterranean countries. With all of these considerations in mind, water managers are left with the daunting challenge of not only meeting the current demand for water but also sustaining supply as demand grows. In order to discuss these issues in response to such water problems in the Mediterranean, MELIA, the Mediterranean Dialogue for Integrated Water Management project, financed by the 6th Framework Programme of the European Commission, was launched in 2006. 
The scale of the project is considerable: "The MELIA Consortium had 45 partners representing 17 countries from both the EU (Italy, Spain, Cyprus, Greece, Belgium, Malta, Austria, the Netherlands) and the Mediterranean (Turkey, Morocco, Algeria, Tunisia, Egypt, Syria, Lebanon, Jordan, Palestine). These members are split into many different categories which included Research Institutions, Decision-Policy Makers, Water Users, International and Intergovernmental Organizations, NGOs, River Basin Authorities, Water Providers for different users and private companies."

MELIA is part of a broader EU INCO-Med programme, which aimed at creation of opportunities to contribute high-quality and relevant scientific knowledge to issues of mutual concern in European and Mediterranean countries. Water management and other major issues such as risk and conflict prevention, environmental management and food security are addressed through collaboration among the scientists in the EU INCO-Med projects. Sometimes collaborative projects offer scientific knowledge, often without resulting in impacts of the challenging situation on the collaborating countries. Such projects lack dialogue between the researchers and all the interested stakeholders. In 2000, the EU issued the Water Framework Directive (WFD), outlining a framework and legislation related to Integrated Water Resources Management (IWRM). This document was the result of 10 years of dialogue and collaboration between the key European stakeholders. It considers water quantity and quality management on an international scale and as a political process. It is generally regarded as a model and reference point for water management issues. MELIA hoped to use the knowledge and experiences gained in creating the Water Framework Directive in combination with local knowledge and shared culture to drive Integrated Water Resources Management in Mediterranean countries. The main aims of MELIA were as follows: to build a knowledge base for Integrated Water Resources Management planning based on the general frame set out by the EU Water Framework Directive and to propose participatory mechanisms and prevention tools to avoid competition for resources between regions, states and different end users.

Secretary General of CIHEAM

Director IAM Bari
Francisco Mombiela Muruzabal Cosimo Lacirignola 


\section{Contents}

\section{Part I IWRM in the Mediterranean Region}

Transboundary IWRM Attempts in the Mediterranean Emphasis on the Drin River Case and the Involvement of Stakeholders

Michael Scoullos

Integrated Water Management in Tunisia: Meeting the Climate Change Challenges

N. Omrani and M. Ouessar

Improving Agricultural Water Productivity: A Viable Response to Water Scarcity in the Dry Areas

Theib Y. Oweis

Conceptual Frame on Technological Perspective for Water Resources Management in the Mediterranean Region

Ayman Rabi, Isabel Martín, and Rafael Rodriguez-Clemente

Part II Water Resources Management Under Climate and Land Use Changes in the Mediterranean Region

Water Resources Management Under Possible Future Climate and Land Use Changes: The Application of the Integrated Hydrological Modelling System, IHMS

R. Ragab, J. Bromley, D.R. D'Agostino, N. Lamaddalena,

G. Trisorio Luizzi, G. Dörflinger, S. Katsikides, S. Montenegro, and A. Montenegro

Challenges and Issues on Measuring, Modelling and Managing the Water Resources Under Changing Climate and Land Use Ragab Ragab 
Water Valuation in Agriculture in the Souss-Massa Basin (Morocco) 109

Fouad Elame and Rachid Doukkali

\section{Part III Non Conventional Water Managements and Pollution Control}

Perspectives of Wastewater Reuse in the Mediterranean Region

Redouane Choukr-Allah

Wastewater Production, Treatment and Reuse Around the Mediterranean Region: Current Status and Main Drivers

Maite Guardiola-Claramonte, Toshio Sato, Redouane Choukr-Allah, and Manzoor Qadir

Pollution and Measures Towards De-pollution of the Mediterranean Sea

Rasha El-Kholy, Aiman El-Saadi, and Alaa El-Din Abdin

Recycling and Reuse of Treated Wastewater: Challenges and Perspectives - The Example of the Júcar River Basin District and the Albufera Lake 195

Javier Ferrer Polo

\section{Part IV Water Polices, Governance and Social Issues}

Mediterranean Water Outlook: Perspective on Policies and Water Management in Arab Countries

Khaled M. AbuZeid

Identifying Risks, Actions, and Opportunities for a Long-Term

Water Strategy in the Mediterranean

Rafael Rodríguez-Clemente and Ana Hidalgo

Mediterranean Water Policies Conceptual Framework 253

Gaëlle Nion

Effective Water Governance and How to Achieve.

A. Hamdy and Redouane Choukr-Allah

Water and Food Security in the Arab Region

Safwat Abdel-Dayem and Rachael McDonnell

Analysis of Gender Roles Related to Water Resources Management in the Case of APP Fruit Tree Planting Project

in the Béni Mellal Area.

Fatema Mosseddaq, D.J. Mulla, and Viviane Ndamba Faye 
Integrated Participatory Water Resources Management and Water Governance.

Doris Schnepf and Stephan Lutter

Violence, the Bitit Canal and the Nile Basin: An Asymmetric

Comparison

Jack Kalpakian, Ahmed Legrouri, Fatima Ejekki, Khalid Doudou,

Fouad Berrada, Abdelkrim Ouardaoui, and Driss Kettani

General Conclusions

Acknowledgments

Abbreviations

Index

357 